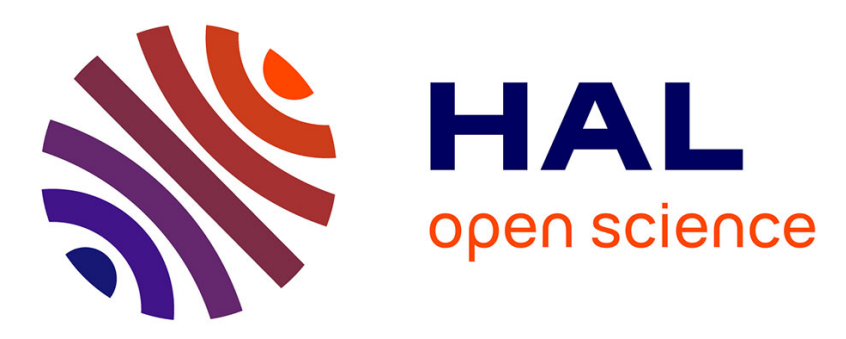

\title{
Persistence of Cry toxins and cry genes from genetically modified plants in two agricultural soils
}

Elisa Marchetti, Cesare Accinelli, Valentina Talamè, Rosanna Epifani

\section{To cite this version:}

Elisa Marchetti, Cesare Accinelli, Valentina Talamè, Rosanna Epifani. Persistence of Cry toxins and cry genes from genetically modified plants in two agricultural soils. Agronomy for Sustainable Development, 2007, 27 (3), pp.231-236. hal-00886370

\section{HAL Id: hal-00886370 \\ https://hal.science/hal-00886370}

Submitted on 1 Jan 2007

HAL is a multi-disciplinary open access archive for the deposit and dissemination of scientific research documents, whether they are published or not. The documents may come from teaching and research institutions in France or abroad, or from public or private research centers.
L'archive ouverte pluridisciplinaire HAL, est destinée au dépôt et à la diffusion de documents scientifiques de niveau recherche, publiés ou non, émanant des établissements d'enseignement et de recherche français ou étrangers, des laboratoires publics ou privés. 


\title{
Persistence of Cry toxins and cry genes from genetically modified plants in two agricultural soils
}

\author{
Elisa MARchETTI, Cesare Accinelli*, Valentina TALAMÈ, Rosanna EPIFANI \\ Department of Agro-Environmental Science and Technology, University of Bologna, Viale Fanin 44, 40127 Bologna, Italy
}

(Accepted 20 February 2007)

\begin{abstract}
The environmental impact of genetically modified crops has been the subject of intense research in the past decade. Since the introduction of insect-resistant crops in 1996, cultivation of this group of genetically modified crops has grown substantially. Most insectresistant varieties, including corn and cotton, have been engineered to express crystal (Cry) toxins. Although several studies concerning the environmental fate of this group of insecticidal toxins have been conducted during the past decade, conflicting information exists dealing with the persistence of Cry toxins in soil. In the present investigation, the persistence of antilepidopteran Cry1 Ab and Cry1 Ac toxins in two different agricultural soils was studied. The potential of $c r y 1 A b$ genes to persist in soil was also estimated. The results from this laboratory investigation indicated that the two toxins dissipated rapidly in both the sandy and in the clay loam soil. The two toxins showed similar degradation rates in soil. During the 35-day incubation period, more than 92 and 79\% of the initial amount of Cry toxins dissipated in the sandy and clay loam soil, respectively. Extractable fractions of the two toxins were lower in the fine-textured soil with respect to the coarse soil. Reduced recovery efficiency from the clay loam soil and thus bioavailability were presumably involved in the lower decline of Cry toxins in this soil. Investigations conducted with an insect-resistant transgenic corn hybrid showed no detectable levels of $c r y 1 A b$ genes in soil six months after plant harvest.
\end{abstract}

genetically modified crops / microbial insecticides / soil persistence / Cry toxins / Bacillus thuringiensis

\section{INTRODUCTION}

Genetically modified (GM) crops are currently cultivated in 21 countries, with an estimated global area of approximately 90 million ha (James, 2005). Major transgenic traits include herbicide tolerance and insect resistance. Insect-resistant varieties have been engineered to express Bacillus thuringiensis $(\mathrm{Bt})$ toxins. $\mathrm{Bt}$ is a ubiquitous spore-forming bacterium that produces a crystalline parasporal body comprised of one or more insecticidal crystal (Cry) proteins. Strains of Bt that are toxic to lepidopteran and other insect orders have been known for almost 100 years, and have been commercialized for more than four decades. Bt-based formulations are widely used in integrated pest management and organic farming programs due to the toxin's high selectivity, and low toxicity to mammals and to non-target insects (Clark et al., 2005).

The environmental impact of insect-resistant crops has been the subject of several laboratory and field investigations over the last decade. Most of the available information has examined the environmental impact of the "aboveground" portion of agricultural systems cultivated with Bt-protected crops, i.e. dispersal and invasiveness of Bt plants into ecosystems, development of resistance in target insects, etc. (Motovalli et al., 2004). Research indicates that Bt crops may exude Cry toxins from roots into the soil or release the toxins through decomposition of crop residues (Palm et al., 1994; Blackwood and

*Corresponding author: cesare.accinelli@unibo.it
Buyer, 2004). In recent years, concerns dealing with the environmental fate of Cry toxins in the soil ecosystem have been expressed in public and scientific debate, but have not yet been adequately addressed (Devare et al., 2004). Current studies show no detrimental effects of Cry toxins on soil microorganisms and soil microbially mediated processes (Accinelli et al., 2006). Under some circumstances, however, a transient stimulation of soil microorganisms in soil receiving crop residues containing Cry1Ac toxin was observed (Donegan et al., 1995). According to Tapp and Stotzky (1998), Cry toxins are readily and strongly sorbed on soil particles, thereby reducing their bioavailability to microbial degradation. Some authors found that bound toxins retained their insecticidal activity, persisting in soil for up to six months (Venkateswerlu and Stotzky, 1992; Saxena et al., 2002). On the contrary, other studies indicated a rapid decay rate of Cry toxins in soil, thus excluding the risk of bioaccumulation in soil after continuous cultivation of Bt-protected crops (Head et al., 2002). Working with the Cry1Ac toxin added to a silt loam soil as corn residues or purified toxin, Sims and Holden (1996) estimated half-life values of 8.3 and 1.6 days, respectively. Similar results were reported by other authors (Herman et al., 2001, 2002). According to Clark et al. (2005), contrasting results can partly be caused by differences in soil type, environmental conditions and type of Cry toxin. However, one major source of differences in soil persistence of Cry toxins is the lack of a reliable and accurate analytical method. Another important aspect of the environmental impact of $\mathrm{Bt}$ crops is represented by the 
Table I. Properties of Casal Borsetti (sandy) and Migliarino (clay loam) soils.

\begin{tabular}{lccccccc}
\hline Soil & \multicolumn{2}{c}{ Particle size } & $\mathrm{pH}^{a}$ & Organic C & Culturable Bacteria $^{b}$ & Bt spores $^{c}$ \\
\hline & Sand & Silt & Clay & & & & \\
& & & $1: 2.5$ & $\%$ & & Log CFUs $^{d} \mathrm{~g}^{-1}$ soil \\
\hline Sandy & 87.1 & 4.9 & 8.0 & 7.9 & 0.9 & 6.8 & Not detected \\
Clay Loam & 33.8 & 41.1 & 25.1 & 6.3 & 6.6 & 8.8 & 1.2 \\
\hline
\end{tabular}

${ }^{a}$ Soil $\mathrm{pH}$ measured in 1:2.5 (w/v) soil/deionized water mixture.

${ }^{b}$ Size of culturable bacteria estimated according to the method described in Accinelli et al. (2006).

${ }^{c}$ Number of Bacillus thuringiensis spores estimated according to the method proposed by Travers et al. (1987).

${ }^{d}$ Colony-forming units.

potential release of transgenic DNA into the soil. Similarly to Cry toxins, cry genes can enter the soil by corn residue incorporation or rotting root materials. While evidence for persistence of transgenic plant DNA exists, transformation of plant DNA into soil microorganisms has not been found. In addition, practical implications concerning this point have not yet been well elucidated (Dunfield and Germida, 2004). The main objective of this research was to investigate the persistence of the Cry $1 \mathrm{Ab}$ and Cry1 Ac toxins in two contrasting agricultural soils. The potential of $c r y 1 A b$ genes to persist in the soil ecosystem was also estimated.

\section{MATERIALS AND METHODS}

\subsection{Persistence of Cry toxins in soil}

Two representative soils from the northern corn-growing area of Italy were selected for this study. Surface soil samples $(0-20 \mathrm{~cm})$ were taken from Casal Borsetti $\left(44^{\circ} 34^{\prime} \mathrm{N}\right.$, $\left.12^{\circ} 14^{\prime} \mathrm{E}\right)$ and Migliarino $\left(44^{\circ} 46^{\prime} \mathrm{N}, 11^{\circ} 55^{\prime} \mathrm{E}\right)$. The Casal Borsetti and Migliarino soils were classified as a sandy (Aquic Ustipsamments, mixed, mesic) and as a clay loam soil (Sulfic Endoaquepts, fine-silty, mixed, mesic), respectively. At both locations, soil was collected from fields that have never been cultivated with Bt-protected crops. Soils were air-dried and passed through a $2-\mathrm{mm}$ sieve. Some physico-chemical properties of the soils are given in Table I.

A portion of each soil was thoroughly mixed with Cry1Ac or Cry1 Ab toxin powders to obtain a final concentration of $100 \mu \mathrm{g} \mathrm{g}^{-1}$ soil. Aliquots of these two amended soils were mixed with a sufficient mass of each soil type to obtain a final soil concentration of $1.0 \mu \mathrm{g} \mathrm{g}^{-1}$ soil (air-dried basis). The mixtures were vigorously blended to promote homogeneous distribution of the toxins in the soils, and 20-g aliquots of each soil were weighed into 250-mL glass, screw-capped, Erlenmeyer flasks. Soil moisture was adjusted to the gravimetric content at $-33 \mathrm{kPa}$ using distilled water and samples were incubated in the dark at $25^{\circ} \mathrm{C}$ for 35 days. At different sampling times, samples were removed and analyzed. Three replicates were prepared for each toxin and soil type, and controls consisted of soils with no toxin addition.

\subsection{Cry toxin purification}

Investigations were conducted with two different antilepidopteran Cry toxins: Cry1 Ac and Cry1Ab. The Cry1Ac toxin was obtained from a recombinant strain of $\mathrm{Bt}$ (4Q7/pPFT1Acs) that was donated by the Dept. of Entomology of the University of California, Riverside, CA. Purification of Cry1Ac toxin was done essentially as described in Park et al. (2000). Briefly, the Bt strain was grown in $200 \mathrm{~mL}$ of nutrient broth medium (Difco Co., Detroit, MI) supplemented with $0.5 \%(\mathrm{w} / \mathrm{v})$ glucose and erythromicin $\left(25 \mu \mathrm{g} \mathrm{mL}^{-1}\right)$. Liquid cultures were incubated for $4-5$ days at $30^{\circ} \mathrm{C}$, with shaking, until sporulation and cell lysis was complete. Cells were centrifuged at $6500 \times g$ for $15 \mathrm{~min}$ at $4{ }^{\circ} \mathrm{C}$, suspended in $15 \mathrm{~mL}$ of double-distilled water, and sonicated for $1 \mathrm{~min}$, five times. Aliquots $(5-10 \mathrm{~mL})$ of the samples were loaded onto a discontinuous sucrose gradient $(67-72-79 \% \mathrm{w} / \mathrm{v})$ and centrifuged at $20000 \times g$ for $1 \mathrm{~h}$ at $5{ }^{\circ} \mathrm{C}$. Bands containing crystal inclusions were collected using a fraction collector, dialyzed in water overnight, and lyophilized. The purity of the toxin preparation was assessed by SDS-polyacrilamide gel electrophoresis. The concentration of Cry1Ac toxin was determined using the Lowry method, with BSA as standard. Cry1 Ab toxins were extracted and purified according to the method described in Tapp and Stotzky (1998). Briefly, Dipel 2X (Sipcam S.p.A., Pero, Italy) was initially washed with $1 \mathrm{M}$ sodium chloride and subsequently with deionized water. Each washing was repeated two times. The obtained washed sediment was extracted with a MOPS buffer (0.1 M 3-N-morpholinopropanesulfonic acid, $\mathrm{pH} 7.8$ ) containing $0.5 \mathrm{M}$ dithiothreitol and $1 \mathrm{M}$ potassium thiocyanate. The extract was dialyzed for 8 hours against deionized water and precipitated using ammonium sulfate. The precipitate was centrifugated at $27000 \times g$ and resuspended in deionized water. Finally, the pellet was dialyzed and lyophilized.

\subsection{Cry toxin persistence}

Persistence of the Cry1Ac and Cry $1 \mathrm{Ab}$ toxins in the sandy and clay loam soils was evaluated using two different approaches: soil extraction and enzyme-linked immunosorbent assay (ELISA), and insect bioassay. At different sampling 
times, the soil of each incubated sample was thoroughly mixed. A 5-g aliquot was removed and used for the insect bioassay and the remaining soil was extracted and analyzed by ELISA using the QuantiPlate Kit for Cry1Ab/Cry1Ac (Envirologix, Portland, ME). Soil extraction was performed using a modification of the procedure suggested by the manufacturer. Briefly, soil samples were mixed with extraction buffer at a ratio of 1:5 and shaken at room temperature for $6 \mathrm{~h}$. Samples were centrifuged at $10000 \times g$ for $15 \mathrm{~min}$, and the supernatant filtered through a $0.2-\mu \mathrm{m}$ filter. A $100-\mu \mathrm{L}$ aliquot of filtered supernatant was added to each microplate well and processed as indicated by the manufacturer. Absorbance measurements were done at $405 \mathrm{~nm}$ using a model 3550 microplate reader (Bio-Rad Laboratories Inc., Hercules, CA). A standard curve was obtained using seven concentrations of purified Cry toxin prepared in 100-mM carbonate buffer ( $\mathrm{pH} 10.5)$. Measurements were done in triplicate.

Bioassays with Ostrinia nubilalis (Hübner) larvae were carried out using the following procedure. Aliquots $(5 \mathrm{~g})$ of soil from incubated samples were mixed with a sufficient mass of the specific insect diet using a high-speed vortex. Portions $(5 \mathrm{~g})$ of the obtained soil/diet mixture were added to single 4-cm diameter bioassay cells and five second-instar larvae were added per cell. Cells were closed with a perforated plastic lid and placed in a climatic chamber at $27^{\circ} \mathrm{C}$ and a photoperiod of 16:8 (light:dark). Measurements were conducted in triplicate. Insect mortality was scored after 7 days, and the results were analyzed by probit analysis for the estimation of median lethal concentrations $\left(\mathrm{LC}_{50}\right)$, after correction for mortality.

\subsection{Detection of $c r y$ genes in soil}

The Bt-protected corn hybrid MON810 Yieldgard $^{\mathrm{TM}}$ encoding for Cry $1 \mathrm{Ab}$ toxin, and the corresponding nontransgenic isoline (Monsanto Co., St. Louis, MO) were used for this study. Seeds were provided by the Department of Soil, Water and Climate of the University of Minnesota. The two hybrids were planted in plastic pots $(50-\mathrm{cm}$ diameter and $50-\mathrm{cm}$ high) and grown in a growth chamber at $25^{\circ} \mathrm{C}$. Pots were filled with $20 \mathrm{~kg}$ of the same sandy soil employed in the Cry toxin experiment except that the soil was passed through a 5-mm sieve. At the growth stage R6, plants were harvested, and the soil contained in each pot was incubated in the same conditions for 6 months. During the whole incubation period, soil moisture was maintained near the field capacity. Six months after plant harvest, the soil of each pot was thoroughly mixed using a mechanic shaker. Subsamples were sieved through a $2-\mathrm{mm}$ sieve and stored at $-80^{\circ} \mathrm{C}$.

DNA was extracted from the soil using the PowerSoil ${ }^{\mathrm{TM}}$ DNA isolation kit (MoBio Laboratories Inc., Solana Beach, CA) following the instructions of the manufacturer. Prior to PCR amplification, DNA samples were purified using the Wizard DNA minicolumn (Promega, Madison, WI). Five microliters of $10 \times$ PCR buffer, $2.5 \mu \mathrm{L}$ of a $10 \mu \mathrm{M}$ concentration of each primer, $0.1 \mu \mathrm{L}$ of a $25 \mathrm{mM}$ concentration of each deoxyribonucleoside triphosphate, $3 \mu \mathrm{L}$ of $\mathrm{MnCl}_{2} 25 \mathrm{mM}, 5 \mu \mathrm{L}$

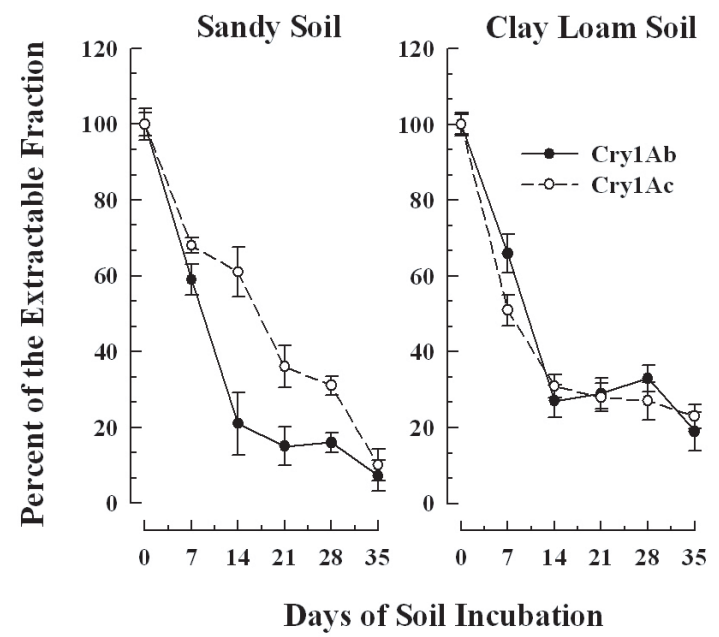

Figure 1. Extractable fractions of Cry1 Ab and Cry1Ac toxins in the sandy and clay loam soils during the 35-day incubation period. Bars represent standard deviations of the means.

soil genomic DNA or $5 \mu \mathrm{L}$ of double-distilled $\mathrm{H}_{2} \mathrm{O}$ (negative control), $0.2 \mu \mathrm{L}$ of Taq DNA polymerase $\left(5 \mathrm{U}^{-1} \mathrm{~L}^{-1}\right)$ and double-distilled $\mathrm{H}_{2} \mathrm{O}$ were combined in a final volume of $50-\mu \mathrm{L}$ PCR mixtures. The primers used to amplify the cry $1 A c$ gene were CJI-1(f) 5'-TGT AGA AGA GGA AGT CTA TCC A-3' and CJI-1(r) 5'-TAT CGG TTT CTG GGA AGT A-3' (Cerón et al., 1995). All products were provided by MBI Fermentas (St. Leon-Rot, Germany). Amplification was done in a T3 DNA thermalcycler (Biometra GmbH, Göttinger, Germany) with the step cycle program set for 30 cycles, each consisting of a 1-min denaturation step at $95^{\circ} \mathrm{C}$, a 1-min annealing step for $48{ }^{\circ} \mathrm{C}$ and a 1-min elongation step at $72{ }^{\circ} \mathrm{C}$. An extra step of extension at $72{ }^{\circ} \mathrm{C}$ for $10 \mathrm{~min}$ was then performed. The presence of amplified products was confirmed by running PCR products on a $1 \%$ agarose gel and staining with SYBR Green I (Sigma Co., St. Louis, MO).

\section{RESULTS AND DISCUSSION}

\subsection{Persistence of Cry toxins estimated by the soil extraction/ELISA approach}

The persistence results obtained following the soil extraction/ELISA approach are shown in Figure 1. As expected, a fraction of added Cry toxins remained unextractable from the soil. No significant differences $(P>0.05)$ of recovery efficiency between the two toxins were observed. Average recovery efficiencies were of 82 and $67 \%$ in the sandy and in the clay loam soil, respectively (Fig. 2). The tendency of fine-textured particles to selectively and strongly retain Cry toxins is documented in the literature (Venkateswerlu and Stotzky, 1992). Since a portion of the added Cry toxin remained unrecoverable from soil, the persistence data obtained by adopting the soil extraction/ELISA approach are referred to as the extractable fraction. The two soils showed a high potential to degrade the 


\section{Recovery of Cry toxins from soil}

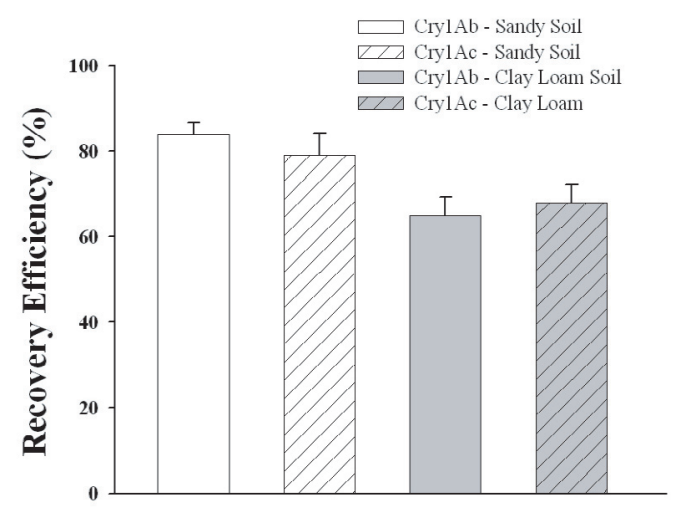

Figure 2. Recovery efficiency of Cry1 Ab and Cry1Ac toxins from the sandy and clay loam soils. Bars represent standard deviations of the means.

Cry $1 \mathrm{Ab}$ and Cry $1 \mathrm{Ac}$ toxins. At the end of the 35-day incubation period, the remaining extractable fractions of Cry $1 \mathrm{Ab}$ and Cry1Ac toxins from the sandy soil were 7 and $10 \%$ of the extractable initial amount, respectively. The half-lives of Cry $1 \mathrm{Ab}$ and Cry1Ac toxins in the sandy soil were calculated assuming the first-order decay model. The regression coefficients of the log-transformed first-order model for the two soils were $>0.89$. The estimated half-lives of the extractable Cry $1 \mathrm{Ab}$ and Cry1Ac toxins were 9.8 and 12.7 days, respectively. Contrary to the sandy soil, the extractable fractions of the two Cry toxins from the clay loam soil showed a rapid decline during the first 2 weeks, followed by a slower decrease over the remaining incubation time (Fig. 1). At the end of the incubation period, the extractable fractions of the Cry $1 \mathrm{Ab}$ and Cry $1 \mathrm{Ac}$ toxins were 19 and $23 \%$ of the initial recovered amount, respectively. The persistence data did not adequately fit the first-order or other decay models. Consequently, no correct comparison of the two soils was permitted. However, on the basis of the remaining extractable fractions, the two Cry toxins seemed to persist longer in the clay loam than in the sandy loam soil.

In the present study, Cry toxins were applied at the concentration of $1 \mu \mathrm{g} \mathrm{g}^{-1}$ soil. Some authors estimated that incorporation of crop residues from Cry1 A-protected plants into the soil is expected to lead to a toxin concentration in the top 1-2 cm ranging from 0.65 to $2.8 \mu \mathrm{g} \mathrm{g}^{-1}$ (Clark et al., 2005). The low persistence of the two employed Cry toxins observed in the present study is consistent with data reported in other laboratory and field investigations, thus further excluding potential risks of bioaccumulation in soil after continuing cultivation of Cry1 Ab- and Cry1Ac-protected plants (Palm et al., 1996; Head et al., 2002).

Although ELISA has been widely used for detecting Cry toxins in plant tissues and food samples, the results of the present experiment showed that toxin extractability from soil can represent a limiting factor for such kinds of investigations. Studies have indicated that Cry toxins are strongly sorbed on soil (Tapp and Stotzky, 1998). On the basis of the concept that ingested Cry toxins are efficiently extracted and solubilized in the gut of sensitive larvae, buffer solutions simulating insect gut fluid have been proposed for toxin extraction from soil. Using a commercial buffer solution, Accinelli et al. (2006) achieved satisfactory recovery of Cry1Ac toxin from coarse soils. Working with different Cry toxins, including the Cry $1 \mathrm{Ab}$ and Cry1 Ac, and a wide range of soil types, Shan et al. (2005) obtained recovery efficiencies $>75 \%$. These results were obtained with an artificial buffer solution simulating the gut fluid of the marine worm Arenicola brasiliensis (Nonato). The results from the present experiment indicate that under some circumstances (i.e. fine-textured soils), the soil extraction/ELISA approach would not give satisfactory and comparable results. More research on mechanisms involved in Cry toxin sorption on soil particles is consequently needed.

\subsection{Insect bioassay and detection of $\operatorname{cry} 1 A b$ genes}

As indicated by the data presented in Table II, the Cry1 Ab toxin showed a significantly higher $(P<0.05)$ level of toxicity against $O$. nubilalis larvae than the Cry1Ac. For both the $\mathrm{Cry} 1 \mathrm{Ab}$ and Cry1 Ac toxins, biological activity estimated as median lethal concentration $\left(\mathrm{LC}_{50}\right)$ declined more rapidly in the sandy than in the clay loam soil. These findings are consistent with those described above. On the basis of the specific mode of action of Cry toxins, modifications of toxin structure are expected to lead to a significant variation in their insecticidal activity (Nuñez-Valdez et al., 2001). The rapid decrease in insecticidal activity suggests that the biological activity of the two Cry toxins would not persist in soil. In relative terms, the decline in biological activity was more intense than that of the extractable toxin residues estimated using the soil extraction/ELISA approach. These findings would be due to modification of the structure of the toxins being in contact with soil particles. As shown with the soil extraction/ELISA approach, the insect bioassay data underlined the more rapid decline in biological activity of the two toxins in the sandy than in the clay loam soil. Studies have indicated that $O$. nubilalis larvae can efficiently extract Cry toxins from soil particles and that degradation of Cry toxins in soil occurs mainly by microbial, rather than by chemical processes (Accinelli et al., 2006). Although the number of culturable bacteria was higher in the clay loam than in the sandy soil (Tab. I), the obtained results suggest that bioavailability of Cry toxins would represent an important factor influencing the persistence of their insecticidal activity in soil. Insect bioassays are commonly conducted by mixing a matrix (i.e. plant tissues, food, etc.) to be measured to a specific insect diet. Contrary to the former matrices, no standardized methods concerning soil samples are available.

Another important aspect is that the presence of indigenous inhibitory and toxic substances or Bt spores in soil cannot be excluded. The bacterium B. thuringiensis is widely distributed in the environment and can commonly be isolated from soil. Bt survives in the soil as spores (Petras and Casida, 1985; Hendriksen and Hansen, 2002). Despite the fact that spores can enhance the activity of Cry toxins per se, once ingested by a susceptible insect, crystal inclusions of Bt spores are solubilized in the insect midgut and Cry toxins released. Other Cry 
Table II. Comparative median lethal concentrations $\left(\mathrm{LC}_{50}\right) \pm$ S.E. (standard error of the mean) of Cry1Ab and Cry1Ac toxins in soil samples over the incubation period.

\begin{tabular}{lllllll}
\hline & \multicolumn{5}{c}{$\mathrm{LC}_{50}\left(\mu \mathrm{g}\right.$ toxins $\mathrm{g}^{-1}$ soil slurry-diet mixture $)$} \\
\hline & \multicolumn{5}{c}{ Sandy Soil } & \multicolumn{3}{c}{ Clay Loam Soil } \\
& 0 Days & 14 Days & 35 Days & 0 Days & 14 Days & 35 Days \\
\hline Cry1Ab & $2.5 \pm 0.3$ & $15.0 \pm 0.5$ & $43.3 \pm 9.9$ & $3.1 \pm 0.9$ & $8.2 \pm 4.1$ & $27.3 \pm 3.7$ \\
\hline Cry1Ac & $4.9 \pm 0.5$ & $28.9 \pm 2.5$ & $79.1 \pm 12.1$ & $4.4 \pm 1.4$ & $13.0 \pm 3.4$ & $41.2 \pm 9.5$ \\
\hline
\end{tabular}

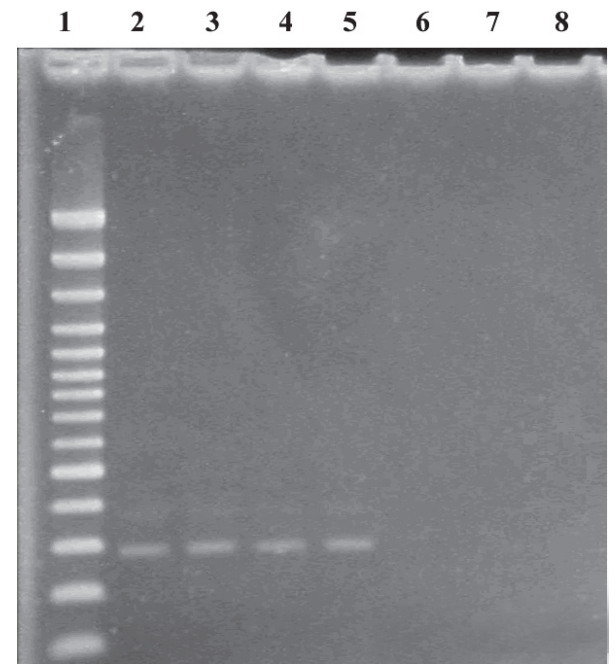

Figure 3. PCR amplification and $c r y 1 A b$ gene detection. Lane 1: dig ladder; lanes 2-5: positive control; lane 6: negative control; lanes 7-8: incubated soil samples.

toxins are released after spore germination and cell sporulations (Mohd-Salleh and Lewis, 1982; West et al., 1984). Considering that $\mathrm{Bt}$ spores can persist much longer in soil than Cry toxins, presence of indigenous Bt spores should be considered in studies concerning the persistence of Cry toxins in soil. Contrary to the sandy soil, Bt spores were detected in the clay loam soil (Tab. I). This latter soil was collected from a corn field located in proximity to apple and pear orchards which are frequently treated with Bt-based insecticides. Aside from the lower bioavailability, the presence of Bt spores in the clay loam soil would be another factor involved in the increase in Cry toxin persistence in soil.

PCR analysis of total DNA extracted from soil containing a known amount $(2 \% \mathrm{w} / \mathrm{w})$ of residues obtained from the GM corn hybrid allowed the detection of the specific DNA construct (Fig. 3). Amplification of the $c r y 1 A b$ gene yielded a single band of the expected size (approximately $272 \mathrm{bp}$ ). No visible bands of the PCR products obtained from soil samples taken from pots planted with the Bt hybrid were observed. Persistence of cry genes in soil is not well documented in the literature. Some authors found that transgenic DNA binds to finetextured soil particles and thus persists longer in soil (Widmer et al., 1996; Franchi et al., 1999; Stotzky, 2000). The obtained results indicate that DNA released by decaying corn roots was under the detectable limit. These findings are compatible with low potential to release transgenic DNA. Considering that soil samples were taken 6 months after corn harvest and that the whole experiment was conducted under conditions supporting optimal microbial growth (soil moisture and temperature), a rapid dissipation of the eventually released transgenic DNA can be assumed.

\section{CONCLUSION}

Our results demonstrated that the antilepidopteran Cry $1 \mathrm{Ab}$ and Cry1Ac toxins are rapidly degraded in soil, thus excluding the potential risk of bioaccumulation in the soil ecosystem. On the basis of the soil extraction data, available fractions of Cry toxins to soil microorganisms would be lower in the clay loam than in the sandy soil. Since persistence of Cry toxins was more rapid in the former soil, toxin bioavailability would be an important factor influencing the rate of toxin dissipation in soil. This tendency was confirmed by the insect bioassay results. Although an insect bioassay is a time-consuming task, it would provide more comparable data than information resulting from soil extraction and extract analysis. Contrarily to previous experiments, the investigation described here with a Bt-protected corn hybrid grown in a climatic chamber did not show a risk of bioaccumulation of $\operatorname{cry} 1 A b$ in soil.

Acknowledgements: This project was supported by a grant from the Dept. of Agro-Environmental Science and Technology (Progetto DiSTA per i giovani).

\section{REFERENCES}

Accinelli C., Koskinen W.C., Sadowsky M.J. (2006) Influence of Cry1Ac toxin on mineralization and bioavailability of glyphosate in soil, J. Agr. Food Chem. 54, 164-169.

Blackwood C.B., Buyer J.S. (2004) Soil microbial communities associated with Bt and non-Bt corn in three soils, J. Environ. Qual. 33, 832-836.

Cerón J., Ortíz A., Quintero R., Güereca L., Bravo A. (1995) Specific PCR primers directed to identify cryI and cryIII genes within a Bacillus thuringiensis strain collection, Appl. Environ. Microb. 61, 3826-3831.

Clark B.W., Phillips T.A., Coats J.R. (2005) Environmental fate and effects of Bacillus thuringiensis (Bt) proteins from transgenic crops: a review, J. Agr. Food Chem. 53, 4643-4653.

Devare M.H., Jones C.M., Thies J.E. (2004) Effect of Cry3Bb transgenic corn and tefluthrin on the soil microbial community: biomass, activity, and diversity, J. Environ. Qual. 33, 837-843. 
Donegan K.K., Palm C.J., Fieland V.J., Porteus L.A., Ganio L.M., Schaller D.L., Bucao L.Q., Seidler R.J. (1995) Changes in levels, species, and DNA fingerprints of soil microorganisms associated with cotton expressing the Bacillus thuringiensis var. kurstaki endotoxin, Appl. Soil Ecol. 2, 111-124.

Dunfield K.E., Germida J.J. (2004) Impact of genetically modified crops on soil- and plant-associated microbial communities, J. Environ. Qual. 33, 806-815.

Franchi M., Bramanti E., Bonzi L.M., Orioli P.L., Vettori C., Gallori E. (1999) Clay-nucleic acid complexes: characteristics and implications for the preservation of genetic material in primeval habitats, Origins Life Evol. B. 29, 297-315.

Head G., Surber J.B., Watson J.A., Martin J.W., Duan J. (2002) No detection of Cry1Ac protein in soil after multiple years of transgenic Bt cotton (Bollgard) use, Environ. Entomol. 31, 30-36.

Hendriksen N.B., Hansen B.M. (2002) Long-term survival and germination of Bacillus thuringiensis var kurstaki in a field trial, Can. J. Microbiol. 48, 256-261.

Herman R.A., Evans S.L., Shanahan D.M., Mihaliak C.A., Bormett G.A., Young D.L., Buehrer J. (2001) Rapid degradation of Cry1F deltaendotoxin in soil, Environ. Entomol. 30, 642-644.

Herman R.A., Scherer P.N., Wolt J.D. (2002) Rapid degradation of a binary, PS149B1, $\delta$-endotoxin of Bacillus thuringiensis in soil, and a novel mathematical model for fitting curve-linear decay, Environ. Entomol. 31, 208-214.

James C. (2005) Global Status of Commercialized Transgenic Crops. ISAAA Brief 34, ISAAA, Ithaca, NY.

Mohd-Salleh M.B., Lewis L.C. (1982) Toxic effects of spore/crystal ratios of Bacillus thuringiensis on European corn borer larvae, J. Invertebr. Pathol. 39, 290-297.

Motovalli P.P., Kremer R.J., Fang M., Means N.E. (2004) Impact of genetically modified crops and their management on soil microbially mediated plant nutrient transformations, J. Environ. Qual. 33, 816-824.

Nuñez-Valdez M.E., Sànchez J., Lina L., Güereca L., Bravo A. (2001) Structural and functional studies of $\alpha$-helix 5 region from Bacillus thuringiensis Cry1 $\mathrm{Ab} \delta$-endotoxin, Biochem. Biophys. Acta 156, $122-131$.

Palm C.J., Donegan H., Harris D., Seidler R.J. (1994) Quantification in soil of Bacillus thuringiensis var kurstaki $\delta$-endotoxin from transgenic plants, Mol. Ecol. 3, 145-151.
Palm C.J., Schaller D.L., Donegan K.K., Seidler R.J. (1996) Persistence in soil of transgenic plant produced Bacillus thuringiensis var. kurstaki $\delta$-endotoxin, Can. J. Microbiol. 42, 1258-1262.

Park H.W., Bideshi D.K., Federici B.A. (2000) Molecular genetic manipulation of truncated Cry $1 \mathrm{C}$ protein synthesis in Bacillus thuringiensis to improve stability and yield, Appl. Environ. Microbiol. 66, 4449-4455.

Petras S.F., Casida L.E. Jr. (1985) Survival of Bacillus thuringiensis spores in the soil, Appl. Environ. Microb. 50, 1496-1501.

Saxena D., Flores S., Stotzky G. (2002) Vertical movement in soil of insecticidal Cry1Ab protein from Bacillus thuringiensis, Soil Biol. Biochem. 34, 111-120.

Shan G., Embrey S.K., Herman R.A., Wolt J.D., Weston D., Mayer L.M. (2005) Biomimetic extraction of Bacillus thuringiensis insecticidal crystal proteins from soil based on invertebrate gut fluid chemistry, J. Agr. Food Chem. 53, 6630-6634.

Sims S.R., Holden L.R. (1996) Insect bioassay for determining soil degradation of Bacillus thuringiensis subsp. kurstaki Cry1A(b) protein in corn tissue, Environ. Entomol. 25, 659-664.

Stotzky G. (2000) Persistence and biological activity in soil of insecticidal proteins from Bacillus thuringiensis and of bacterial DNA bound on clays and humic acids, J. Environ. Qual. 29, 691-705.

Tapp H., Stotzky G. (1998) Persistence of the insecticidal toxin from Bacillus thuringiensis subsp. kurstaki from soil, Soil Biol. Biochem. 4, 471-476.

Travers R.S., Martin P.A.W., Reichelderfer C.F. (1987) Selective process for efficient isolation of soil Bacillus spp., Appl. Environ. Microb. $53,1263-1266$.

Venkateswerlu G., Stotzky G. (1992) Binding of the protoxin and toxin proteins of Bacillus thuringiensis subsp. kurstaki on clay minerals, Curr. Microbiol. 25, 225-233.

West A.W., Burges H.D., White R.J., Wyborn C.H. (1984) Persistence of Bacillus thuringiensis parasporal crystal insecticidal activity in soil, J. Invertebr. Pathol. 44, 128-133.

Widmer F., Seidler R.J., Watrud L.S. (1996) Sensitive detection of transgenic plant marker gene persistence in soil microcosms, Mol. Ecol. 5, 603-613. 